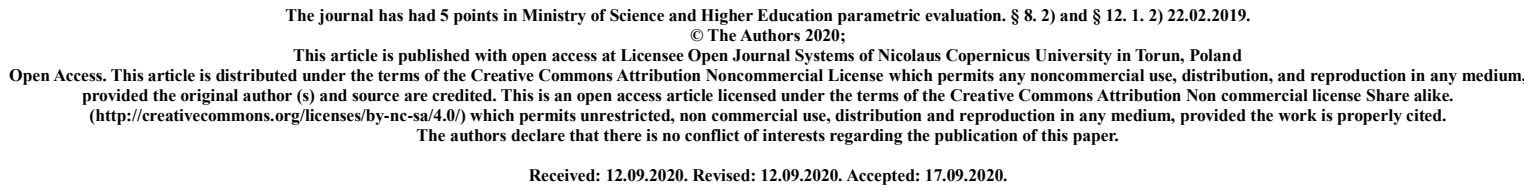

\title{
Lipid disorders in blue-collar workers in Lubelskie region
}

\author{
Paula Jankowska ${ }^{1}$, Krzysztof Jankowski ${ }^{1}$, Ewa Rudnicka-Drożak ${ }^{1}$, Piotr Kamiński ${ }^{2}$ \\ 1. Chair and Department of Family Medicine, Medical University of Lublin \\ 2. Department of Traumatology and Emergency Medicine, Medical University of Lublin
}

\begin{abstract}
Introduction

Lipid disorders are the most important risk factor of cardiovascular disease (CVD). For clinical practice and assessment of patient's cardiovascular risk the most relevant is to determine plasma concentration of low-density lipoprotein cholesterol (LDL-C) and nonhigh-density lipoprotein cholesterol (non-HDL-C). Blue-collar workers are a group of patients with higher estimated cardiovascular risk than other workers groups.
\end{abstract}

\section{The aim of the study}

The aim of the study was to asses prevalence of lipid disorders in blue-collar workers from Lubelskie region.

\section{Material and methods}

The method of this paper was to perform a retrospective analysis of data provided by the National Health Fund. The study population enclosed patients aged 35, 40, 45, 50, 55 included in the Cardiovascular Disease Prevention Program held in Primary Healthcare (PH) setting on the area of Lubelskie region in years 2008-2018. Patients analyzed were blue-collar workers. The chi-square test was used to test the relationship between the two qualitative features and the Pearson linear correlation between the quantitative features. 
The analyzes were performed using the IBM SPSS Statistics for Windows, version 25 program (IBM Corp., Armonk, N.Y., USA). The significance level was assumed to be $\alpha=$ 0,05 .

\section{Results}

In 26226 patients hyperlipidemia was observed in 65,6\% and LDL cholesterol levels higher than $115 \mathrm{mg} / \mathrm{dl}$ in $52,8 \%$ of patients. The mean total cholesterol serum concentration was 203,8 mg/dl, LDL cholesterol - 120,1 mg/dl and median triglycerides concentration - 101,0 $\mathrm{mg} / \mathrm{dl}$.

\section{Conclusions}

Hyperlipidemia was a common problem in blue-collar workers in Lubelskie region in years 2008-2018. Intense prophylactic actions are needed to reduce cardiovascular risk of this group of population.

\section{Key words: Dyslipidemias; Cardiovascular Diseases}

\section{INTRODUCTION}

Lipid disorders are the most important risk factor of cardiovascular disease (CVD). The pivotal role in the patomechanism of cardiovascular complications is credited to ApoB lipoprotein, mainly ApoB-100 and ApoB-48 [1]. Commonly tested particles rich in atherogenic compounds are LDL and less frequently examined VLDL, IDL and chylomicrones and their remnants [2]. For clinical practice and assessment of patient's cardiovascular risk the most relevant is to determine plasma concentration of low-density lipoprotein cholesterol (LDL-C) and non-high-density lipoprotein cholesterol (non-HDL-C) [3]. According to the European Society of Cardiology (ESC) and the European Atherosclerosis Society (EAS) recommendations in general population which is estimated to be at low cardiovascular risk level the LDL-C level $<3.0 \mathrm{mmol} / \mathrm{l}(<116 \mathrm{mg} / \mathrm{dl})$ should be maintained. Patients in moderate risk group should present LDL-C concentrations <2.6 $\mathrm{mmol} / \mathrm{l} \quad(<100 \mathrm{mg} / \mathrm{dl})$. Whereas, for high risk and very high risk the values advised are respectively $<1.8 \mathrm{mmol} / 1(<70 \mathrm{~m} / \mathrm{dl})$ and $<1.4 \mathrm{mmol} / 1(<55 \mathrm{mg} / \mathrm{dl})[4]$.

Blue-collar workers are the group of patients who, according to many studies, are more prone to develop hypertension [5]. The total cardiovascular risk is estimated to be higher in this group of workers additionally due to greater risk of development of diabetes mellitus and higher prevalence of smoking in comparison to white-collar workers [6]. Whereas, there is some inconsistent data about the presence of hypercholesterolemia in working population.

\section{THE AIM OF THE STUDY}

The aim of the study was to asses prevalence of lipid disorders in blue-collar workers from Lubelskie region. 


\section{MATERIAL AND METHODS}

The method of this paper was to perform a retrospective analysis of data provided by the National Health Fund. The study population enclosed patients aged 35, 40, 45, 50, 55 included in the Cardiovascular Disease Prevention Program held in Primary Healthcare (PH) setting on the area of Lubelskie region in years 2008-2018. Patients analyzed were blue-collar workers. The sociodemographic variables were obtained using a survey questionnaire and blood pressure, heart rate, anthropometric measurements and laboratory test results (full lipid profile, fasting glucose) were performed by $\mathrm{PH}$ employees.

The lipid profile values were described by the mean value and standard deviation (SD) or the median (M) and lower (q1) and upper (q3) of the quartile depending on the distribution of the variable. Normal distribution of a variable was assessed using the Shapiro-Wilk test. The chi-square test was used to test the relationship between the two qualitative features and the Pearson linear correlation between the quantitative features. The analyzes were performed using the IBM SPSS Statistics for Windows, version 25 program (IBM Corp., Armonk, N.Y., USA). The significance level was assumed to be $\alpha=0,05$.

\section{RESULTS}

In this study we analyzed data from 26226 prophylactic visits held in General Practice setting. Sociodemographic data 40 -year-old patients were the most numerous group. Men predominated in the research group.

\begin{tabular}{|l|c|c|}
\hline Age & n & \% \\
\hline $\mathbf{3 5}$ & 6631 & 25,28 \\
\hline $\mathbf{4 0}$ & 6283 & 23,96 \\
\hline $\mathbf{4 5}$ & 5499 & 20,97 \\
\hline $\mathbf{5 0}$ & 4504 & 17,17 \\
\hline $\mathbf{5 5}$ & 3309 & 12,62 \\
\hline
\end{tabular}

Table 1. Structure of age.

\begin{tabular}{|l|c|c|}
\hline Sex & n & \% \\
\hline men & 13566 & 51,73 \\
\hline women & 12660 & 48,27 \\
\hline
\end{tabular}

Table 2. Sex distribution.

\section{Lipid profile}

Mean values of different fractions of cholesterol were higher than normal limits. In contrast to this mean value of triglycerides was lower than normal limit.

\begin{tabular}{|l|c|c|c|c|}
\hline [mg] & Mean & Min. & Max & SD \\
\hline T-Chol & 203,8448 & 12,00000 & 764,000 & 40,0325 \\
\hline HDL-C & 59,1277 & 4,00000 & 200,000 & 18,1288 \\
\hline LDL-C & 120,0863 & 10,00000 & 518,000 & 35,5842 \\
\hline
\end{tabular}

Table 3. Serum concentrations of cholesterol fractions in research population. 


\begin{tabular}{|c|c|c|c|c|c|}
\hline Median & Min. & Max. & Q1 & Q3 & SD \\
\hline 101,0000 & 11,00000 & 5527,000 & 73,00000 & 147,0000 & 110,5402 \\
\hline
\end{tabular}

Table 4. Serum concentration of triglycerides in research population.

Hyperlipidemia defined as serum concentration of total cholesterol $\geq 190 \mathrm{mg} / \mathrm{dl}$ and/or LDL-C $\geq 115 \mathrm{mg} / \mathrm{dl}$ was observed in near $2 / 3$ of patients. It was the most common abnormality in laboratory test results among tested patients. In turn, slightly over $50 \%$ of respondents presented elevated concentrations of LDL-C cholesterol.

\begin{tabular}{|l|c|c|}
\hline Hyperlipidemia & $\mathbf{n}$ & $\boldsymbol{\%}$ \\
\hline No & 8980 & 34,24 \\
\hline Yes & 17194 & 65,56 \\
\hline
\end{tabular}

Table 5. Hyperlipidemia in research population.

\begin{tabular}{|l|c|c|}
\hline $\begin{array}{l}\text { T-Chol- } \\
\text { C } \\
\text { [mg/dl] }\end{array}$ & $\mathbf{n}$ & \% \\
\hline$<\mathbf{1 9 0}$ & 9992 & 38,10 \\
\hline$\geq \mathbf{1 9 0}$ & 16234 & 61,90 \\
\hline
\end{tabular}

Table 6. Increased total cholesterol in research population.

\begin{tabular}{|l|c|c|}
\hline $\begin{array}{l}\text { LDL-C } \\
\text { [mg/dl] }\end{array}$ & $\mathbf{n}$ & $\boldsymbol{\%}$ \\
\hline$<\mathbf{1 1 5}$ & 12020 & 45,83 \\
\hline$\geq \mathbf{1 1 5}$ & 13850 & 52,81 \\
\hline
\end{tabular}

Table 7. Increased LDL cholesterol in research population.

Severe increase in LDL-C concentration (LDL-C $\geq 330 \mathrm{mg} / \mathrm{dl}$ ) was observed only in 12 patients $(0,05 \%)$.

Majority of patients showed normal serum concentrations of triglycerides and only 58 patients presented severe hypertriglyceridemia $(0,2 \%)$. Atherogenic dyslipidemia defined as elevated TG levels and HDL-C levels $<1.0 \mathrm{mmol} / \mathrm{l}(40 \mathrm{mg} / \mathrm{dl})$ in men and $<1.2 \mathrm{mmol} / \mathrm{l}(45 \mathrm{mg} / \mathrm{dl})$ in women was found in $6 \%$ of the subjects $(n=1574)$.

\begin{tabular}{|l|c|c|}
\hline $\begin{array}{l}\text { TG } \\
{[\mathbf{m g} / \mathbf{d l}]}\end{array}$ & $\mathbf{n}$ & $\boldsymbol{\%}$ \\
\hline$<\mathbf{1 5 0}$ & 19909 & 75,91 \\
\hline$\geq \mathbf{1 5 0}$ & 6317 & 24,09 \\
\hline
\end{tabular}

Table 8. Hypertriglyceridemia in research population. 
The correlation between selected lipid parameters and undertaking physical activity was assessed. No significant correlation was observed between the occurrence of LDL-C concentrations equal to or greater than $115 \mathrm{mg} / \mathrm{dl}$ and physical activity. The same relationship was observed between level of physical activity and other lipid parameters. Abnormal LDL-C concentration did not correlate with the presence of a premature cardiovascular event in the father or mother.

Although body mass assessed with use of BMI positively correlated with presence of increased concentration of LDL-C.

\begin{tabular}{|c|c|c|}
\hline \multirow{3}{*}{$\begin{array}{l}\text { BMI } \\
{[\mathrm{kg} / \mathrm{m} 2]}\end{array}$} & \multicolumn{2}{|c|}{ LDL-C [mg] } \\
\hline & $<115$ & $\geq 115$ \\
\hline & $\mathbf{n}$ & $\mathbf{n}$ \\
\hline$<18,5$ & 164 & 93 \\
\hline $\begin{array}{l}18,5- \\
24,99\end{array}$ & 5596 & 4593 \\
\hline $\begin{array}{l}25,0- \\
29,99\end{array}$ & 4399 & 6236 \\
\hline $\begin{array}{l}30,0- \\
34,99\end{array}$ & 1453 & 2420 \\
\hline $\begin{array}{l}35,0- \\
39,99\end{array}$ & 328 & 424 \\
\hline$\geq 40,0$ & 80 & 84 \\
\hline
\end{tabular}

Table 9. Body mass (acc. to BMI) and hypercholesterolemia LDL.

Further, waist circumference positively correlated with higher prevalence of abnormal LDL-C concentration. According to recommendations correct waist circumference was set as $<94 \mathrm{~cm}$ in men and $<80 \mathrm{~cm}$ in women.

\begin{tabular}{|l|c|c|}
\hline \multirow{2}{*}{$\begin{array}{l}\text { Waist } \\
\text { circumference }\end{array}$} & \multicolumn{2}{|c|}{ LDL-C [mg] } \\
\cline { 2 - 3 } & $\mathbf{1 1 1 5}$ & $\mathbf{\geq 1 1 5}$ \\
\cline { 2 - 3 } Normal & $\mathbf{n}$ & $\mathbf{n}$ \\
\hline Abnormal & 6945 & 5327 \\
\hline \multicolumn{3}{|c|}{$\mathbf{p}<\mathbf{0 , 0 0 1}$} \\
\hline
\end{tabular}

Table 10. Waist circumference and hypercholesterolemia LDL. 


\section{DISCUSSION}

The analyzed population of blue-collar workers showed high serum concentrations of lipids. The mean values of total cholesterol and LDL-C cholesterol are higher than recommended concentration for general population according to ESC/EAS document. Median concentration of triglycerides was within normal limits (below $150 \mathrm{mg} / \mathrm{dl}$ ). Hyperlipidemia defined as serum concentration of total cholesterol $\geq 190 \mathrm{mg} / \mathrm{dl}$ and/or LDL-C $\geq 115 \mathrm{mg} / \mathrm{dl}$ was observed in vast population of near $2 / 3$ of patients. More than one half of patients presented with elevated concentrations of the most important fraction of cholesterol LDL-C. What is interesting, there was no correlation between concentrations of cholesterol and level of physical activity found. Contrarily, body mass expressed as a BMI value and waist circumference correlated positively. WOBASZ II study described significantly lower rates of hypercholesterolemia. It was $49 \%$ of men and $58 \%$ of women [7]. From Polish nationwide perspective hypercholesterolemia was present in $55-60 \%$ of general population, which is a result near obtained in this study [8-11].

Noteworthy are also results concerning the problem of severe hypercholesterolemia. LDL-C levels $\geq 330 \mathrm{mg} / \mathrm{dl}$ were observed in $0.05 \%$ of patients $(\mathrm{n}=12)$. Such a high concentration of LDL cholesterol should be a signal for a doctor to suspect familial hypercholesterolaemia [12]. This condition is connected with even hundred times higher total cardiovascular risk [13]. A meta-analysis of Polish population studies found that HeFH may occur in Poland with a frequency of $404 / 100,000$ population [14]. The extrapolation of that fact may bring an estimation of presence of 106 patients with heterozygous familial hypercholesterolemia, whereas only 12 patients were identified.

Hypertriglicerydemia was observed in near quarter of respondents. In Polish population studies the prevalence of this lipid disorder was $30-37 \%[8,10,15,16]$.

Atherogenic dyslipidemia defined was found in $6 \%$ of respondents. Meta-analysis of European studies showed that atherogenic dyslipidemia may be presenet in even $9.9 \%$ of whole population [17]. In this perspective our result is relatively not very high, especially when the accepted criteria for diagnosis are compared (in our study TG $\geq 150 \mathrm{mg} / \mathrm{dl}$ and HDLC $40 \mathrm{mg} / \mathrm{dl}$ in men and $<45 \mathrm{mg} / \mathrm{dl}$ and in meta-analysis TG $\geq 200 \mathrm{mg} / \mathrm{dl}$ and $\mathrm{HDL}<40 \mathrm{mg}$ / $\mathrm{dl})$.

\section{CONCLUSIONS}

Hyperlipidemia was a common problem in blue-collar workers in Lubelskie region in years 2008-2018. This is highly disquieting fact because may lead to macrovascular complications. Intense prophylactic actions are needed to reduce cardiovascular risk of this group of population. 


\section{REFERENCES}

1. Tabas I, Williams KJ, Borén Jan. Subendothelial lipoprotein retention as the initiating process in atherosclerosis: update and therapeutic implications. Circulation 2007;116:1832-44.

2. Do R, Willer CJ, Schmidt EM, Sengupta S, Gao C, Peloso GM, et al. Common variants associated with plasma triglycerides and risk for coronary artery disease. Nature Genetics 2013;45:1345-52.

3. Colantonio LD, Bittner V, Reynolds K, Levitan EB, Rosenson RS, Banach M, et al. Association of Serum Lipids and Coronary Heart Disease in Contemporary Observational Studies. Circulation 2016;133:256-64.

4. Mach F, Baigent C, Catapano AL, Koskinas KC, Casula M, Badimon L, et al. 2019 ESC/EAS Guidelines for the management of dyslipidaemias: lipid modification to reduce cardiovascular risk European Heart Journal 2020;41:1:111-88.

5.Aginsky KD, Constantinou D, Delport M, Watson ED. Cardiovascular Disease Risk Profile and Readiness to Change in Blue- and White-Collar Workers. Fam Community Health. 2017;40(3):236-244.

6. Kelsall HL, Fernando PHS, Gwini SM, Sim MR. Cardiovascular Disease and Type 2 Diabetes Risk Across Occupational Groups and Industry in a Statewide Study of an Australian Working Population. J Occup Environ Med. 2018;60(3):286-294.

7. Pająk A, Szafraniec K, Polak M, Polakowska M, Kozela M, Piotrowski W, et al.Changes in the prevalence, management and treatment of hypercholesterolemia and other dyslipidemias over 10 years in Poland. The WOBASZ study. Polish Archives of Internal Medicine 2016;126:9:642-652.

8. Zdrojewski T, Bandosz P, Szpakowski P, Konarski R, Manikowski A, Wołkiewicz E,et al.

Rozpowszechnienie głównych czynników ryzyka chorób układu sercowo-naczyniowego w Polsce. Wyniki badania NATPOL PLUS. [Prevalence of the main risk factors for cardiovascular diseases in Poland. The results of the NATPOL PLUS study.] Kardiologia Polska 2004;61:(Supl. 4):1-26.

9. Zdrojewski T, Solnica B, Cybulska B, Bandosz P, Rutkowski M, Stokwiszewski J, et al. Prevalence of lipid abnormalities in Poland. The NATPOL 2011 survey. Kardiologia Polska 2016:213-23.

10. Pająk A, Wiercińska E, Polakowska M, Kozakiewicz K, Kaczmarczyk-Chałas K, Tykarski A, et al. Rozpowszechnienie dyslipidemii u mężczyzn i kobiet w wieku 20-74 lat w Polsce. Wyniki programu WOBASZ. [Dyslipidemia prevalence in men and women aged 20-74 in Poland. WOBASZ results.] Kardiologia Polska 2005; 63:(Supl. 4):620-6.

11. Pająk A, Szafraniec K, Polak M, Polakowska M, Kozela M, Piotrowski W, et al.Changes in the prevalence, management and treatment of hypercholesterolemia and other dyslipidemias over 10 years in Poland. The WOBASZ study. Polish Archives of Internal Medicine 2016;126:9:642-652.

12. Colantonio LD, Bittner V, Reynolds K, Levitan EB, Rosenson RS, Banach M, et al.Association of Serum Lipids and Coronary Heart Disease in Contemporary Observational Studies. Circulation 2016;133:256-64. 13. Rynkiewicz A, Cybulska B, Banach M, Filipiak K, Guzik T, Idzior-Waluś B, et al. Management of familial heterozygous hypercholesterolemia: Position Paper of the Polish Lipid Expert Forum. Journal of Clinical Lipidology 2013;7:217-21.

14. Pajak A, Szafraniec K, Polak M, Drygas W, Piotrowski W, Zdrojewski T, et al.Prevalence of familial hypercholesterolemia: a meta-analysis of six large, observational,population-based studies in Poland. Archives of Medical Science 2016;4:687-96.

15. Jóźwiak J, Mastej M, Lukas W, Piwowarska W, Konduracka E, Tykarski A. Badanie LIPIDOGRAM2004 vs LIPIDOGRAM 2006. Czy sytuacja epidemiologiczna w zakresie zaburzeń lipidowych uległa zmianie? [Study LIPIDOGRAM2004 vs LIPIDOGRAM 2006. Has the epidemiological situation in the field of lipid disorders changed?] Problemy Medycyny Rodzinnej 2007;9:78-81.

16. Jóźwiak J, Mastej M, Lukas W. LIPIDOGRAM2003 - Ocena i porównanie parametrów pełnego lipidogramu i wskaźnika masy ciała BMI w zależności od płci i wieku w populacjipacjentów Polski południowej i

zachodniej. Część II: częstość występowania zaburzeń lipidowych w zależności od płci i BMI.

[LIPIDOGRAM2003 - Assessment and comparison of the parameters of the full lipidogram and BMI body mass index depending on gender and age in the population of patients in southern and western Poland. Part II: The incidence of lipid disorders by gender and BMI.] Problemy Medycyny Rodzinnej 2005;7:33-9.

17. Halcox JP, Banegas JR, Roy C, Dallongeville J, Backer GD, Guallar E, et al. Prevalence and treatment of atherogenic dyslipidemia in the primary prevention of cardiovascular disease in Europe: EURIKA, a crosssectional observational study. BMC Cardiovascular Disorders 2017;17:1:160. 